\title{
Sunkiųjų metalų akumuliacija salotose (Lactuca sativa L.), užaugintose kalkių purvu stabilizuotame substrate
}

Eglè Barkauskaitè ${ }^{1}$,

Alfreda Kasiulienè ${ }^{1}$,
Valdas Paulauskass',
Giedrius Šlekys ${ }^{2}$
${ }^{1}$ Aleksandro Stulginskio universitetas,
Studentug.11,
LT-53361 Akademija, Kauno r.
El.paštas valdas.paulauskas@asu.lt
${ }^{2}$ UAB „Arvi cukrus“,
P. Armino g. 65,
LT-68127 Marijampole

Sunkiųjų metalu stabilizavimas naudojant pramonèje susidarančias atliekas yra patrauklus metodas siekiant sumažinti dirvožemio taršą bei žmogui ir aplinkai keliamą pavojų. Šiltnamio vegetacinio eksperimento metu buvo tiriamas cukraus pramonèje susidarančio šalutinio produkto - kalkių purvo - poveikis sunkiujjų metalų akumuliacijai lapinèse salotose (Lactuca sativa L.), užaugintose nuotekų dumblo ir dirvožemio mišinyje. Kalkių purvo priedas labiausiai sumažino kadmio ir cinko bioprieinamumą lapinėms salotoms, augintoms užterštame dirvožemyje. Didejant stabilizuojančio priedo koncentracijai substrate nuo 5 iki $20 \%$, Cd ir Zn akumuliacija salotose reikšmingai sumažėjo. Švino atveju statistiškai patikimas akumuliacijos sumažėimas stebėtas tik esant didžiausiai kalkių purvo koncentracijai $(20 \%)$. Vario atveju statistiškai reikšmingo akumuliacijos skirtumo tarp trijų stabilizuoto substrato variantų nebuvo. Remiantis bioakumuliacijos koeficientais nustatyta, kad sunkieji metalai pagal akumuliacijos gebą salotose, augintose užterštame dirvožemyje, išsidèsto taip: $\mathrm{Cd}>\mathrm{Zn}>\mathrm{Pb}>\mathrm{Cu}$.

Raktažodžiai: lapinè salota (Lactuca sativa L.), sunkieji metalai, bioprieinamumas, akumuliacija, kalkių purvas, nuotekų dumblas

\section{IVADAS}

Nuolat didejjant sunkiujų metalų (SM) koncentracijai dirvožemyje, daroma vis didesnè žala ekosistemoms, taip pat ir žmogui, todèl užteršto dirvožemio būklès ir jo funkcijų atstatymo (remediacijos) technologijos yra labai svarbios. Vienas iš švelnesnių, paprastesnių ir pigesnių tiek in-situ, tiek ir ex-situ taikomų dirvožemio remediacijos metodų - sunkiųjų metalų cheminè stabilizacija. Jos metu naudojamos ivvairios medžiagos (1 lentelè), mažinančios metalų judrumą dirvožemyje ir ribojančios jų prieinamumą augalams. Sunkiųjų metalų imobilizacijai gali būti naudojamos ir ịvairios pramonès srityse susidarančios atliekos - biomasès deginimo pelenai, cemento gamybos atliekos (cemento dulkès), cukraus gamybos atliekos (kalkiu purvas), kalnakasybos ar metalo apdirbimo pramonès atliekos, turinčios geležies, šarminių junginių ar fosfatų turtingos atliekos, taip pat įvairios organinès atliekos. Patrauklu tai, kad sunkiųjų metalų stabilizacijai naudojamos medžiagos dažnai papildo dirvą augalams reikalingais makroelementais $(\mathrm{Ca}, \mathrm{Mg}, \mathrm{K}, \mathrm{N}, \mathrm{P})$, pagerina dirvos struktūrą (Bolan et al., 2014).

Šarminès kilmès medžiagos dèl aukštos $\mathrm{pH}$ (10-12) gali būti naudojamos ir vandenvalos nuoteku dumblui stabilizuoti. Municipalinis nuoteku dumblas dažniausiai būna labai užterštas ịvairiais patogeniniais mikroorganizmais ir parazitais, taip pat sunkiųjų metalų junginiais. Sumaišius nuotekų dumblą su šarminèmis medžiagomis, stabilizuojami jame vykstantys irimo procesai, o dèl pakilusios temperatūros ir $\mathrm{pH}$ žūva parazitų kiaušinèliai, bakterijos ir virusai. Padidejja gauto substrato buferiškumas, išsprendžiama nemalonaus kvapo problema. Be to, lengvai tirpūs sunkiụjų metalų junginiai šarminèje aplinkoje virsta sunkiai tirpiais metalu hidroksidais. Nuotekų dumblo bei ịvairių bioatliekų stabilizacijai ir sterilizacijai taip pat gali būti naudojamos šarminès kilmés pramoninès atliekos, pvz.: 


\section{1 lentelè. Cheminiam sunkiųjų metalų stabilizavimui naudojami priedai}

Table 1. Additives used for heavy metal chemical stabilization

\begin{tabular}{|c|c|c|}
\hline $\begin{array}{c}\text { Priedai } \\
\text { Additives }\end{array}$ & $\begin{array}{l}\text { Pavyzdys } \\
\text { Example }\end{array}$ & $\begin{array}{c}\text { Šaltiniai } \\
\text { References }\end{array}$ \\
\hline $\begin{array}{l}\text { Organinès } \\
\text { medžiagos / atliekos } \\
\text { Organic matter/waste }\end{array}$ & $\begin{array}{l}\text { Medžio pjuvenos, šiaudai, sodo / žaliosios atliekos, } \\
\text { kompostas, naminių paukščiu méšlas } \\
\text { Sawdust, straw, garden/green waste, compost, poultry } \\
\text { manure }\end{array}$ & $\begin{array}{l}\text { Petruzzelli et al., 1998; Keller et al., } \\
\text { 2002; McLaren et al., 2005; } \\
\text { Wu et al., 2012; Mendez, 2012; } \\
\text { Beesley, 2013; Bolan et al., 2014 }\end{array}$ \\
\hline $\begin{array}{l}\text { Geležis ir jos junginiai } \\
\text { Iron, iron compounds }\end{array}$ & $\begin{array}{l}\text { Geležies sulfatas, getito mineralas, geležies dulkès, } \\
\text { drožlès } \\
\text { Ferrous sulphate, goethite mineral, iron dust, shavings }\end{array}$ & $\begin{array}{l}\text { Hartley et al., 2004; Kumpi- } \\
\text { ene et al., 2008; Yan-Jun et al., } \\
\text { 2014; Bolan et al., } 2014\end{array}$ \\
\hline $\begin{array}{l}\text { Ceolitai } \\
\text { Zeolites }\end{array}$ & $\begin{array}{l}\text { Natūralieji, sintetiniai } \\
\text { Natural, synthetic }\end{array}$ & $\begin{array}{l}\text { Zorpas et al., 2000; Moi- } \\
\text { rou et al., 2001; Querol et al., } \\
\text { 2006; Bolan et al., } 2014\end{array}$ \\
\hline $\begin{array}{l}\text { Pramonès atliekos } \\
\text { Industrial waste }\end{array}$ & $\begin{array}{l}\text { Fosfogipsas, raudonasis dumblas, cemento dulkès, } \\
\text { kalkių purvas } \\
\text { Phosphogypsum, red mud, cement dust, lime mud }\end{array}$ & $\begin{array}{l}\text { Friesl et al., 2003; Wirojana- } \\
\text { gud et al., 2004; Seeda et al., 2005; } \\
\text { Šlapakauskas, 2008; Puodžiūnas, } \\
\text { 2009; Bolan et al., } 2014\end{array}$ \\
\hline
\end{tabular}

cemento gamybos atliekos - cemento dulkès. Šis stabilizacijos metodas žinomas N-Viro Soil proceso pavadinimu (Burnham et al., 1992).

Mokslininkai (Zubillaga, Lavado, 2002; van Wyk, 2005; Butnariu, 2012) ištyrè, kad salotos (Lactuca sativa L.) savo audiniuose yra linkusios kaupti kai kurias neorganines druskas, ypač nitratus. Gerokai pavojingesni teršalai - tai lapinèse daržovèse besikaupiantys sunkieji metalai. Salotos gali kaupti įvairius sunkiuosius metalus: tiek biogeninius mikroelementus (pvz., varị, cinką, nikeli, chromą), tiek ir nebiogeninius elementus (gyvsidabrị, kadmį, šviną ir kt.). Ypač dideliais kiekiais salotos akumuliuoja kadmi (Zubillaga, Lavado, 2002). Tarptautinè ekonominio bendradarbiavimo ir plètros organizacija, bendradarbiaujanti su JAV Aplinkos apsaugos agentūra, lapines salotas išskyrè kaip bioindikatorinę rūši vertinant dirvožemio taršą (Brown et al., 1996). Svarbu tai, kad sunkiųjų metalų akumuliacija pačioms salotoms nekelia didesnio streso. Tai yra ypač pavojinga, nes salotos su sukauptais sunkiaisiais metalais nežinant gali būti suvartotos maistui. Kaip prevencinę priemonę Europos Komisija nutarimu $1881 / 2006^{1}$ yra reglamentavusi švino ir kadmio kiekį lapinių salotų drégnojoje

1 Commission Regulation (EC) No. 1881/2006 setting maximum levels for certain contaminants in foodstuffs. 2006. The Commission of the European Communities [žiūrèta 2016-01-18]. Prieiga per internetą: http://eur-lex.europa.eu/legal-content/ LT/TXT/?qid=1453126057239\&uri=CELEX:32006R1881 augalo maseje: $\mathrm{Pb}$ koncentracija neturètų viršyti $0,3 \mathrm{mg} / \mathrm{kg}, \mathrm{Cd}-0,2 \mathrm{mg} / \mathrm{kg}$.

Kalkiu purvas (dar vadinamas defekatu) - tai cukraus pramonès atliekos, turinčios potencialą stabilizuoti sunkiuosius metalus užterštame dirvožemyje, tačiau ši galimybe Lietuvoje nèra išsamiau tyrinèta. Gaminant cukrų iš cukrinių runkelių, kalkių pienas naudojamas valant cukraus sultis (difuzijos syvus). Defektosaturacijos stotyje iš syvų pašalinamos necukrinès medžiagos, kurios apsunkina sacharozės išgavimą. Kalkių pagalba nusodintos necukrinès medžiagos atskiriamos filtruojant - gaunamas kalkiu purvas, kuris sandèliuojamas kaip atlieka. LR atliekų sąraše kalkių purvui priskiriamas kodas 020402 (naudoti netinkamas kalcio karbonatas) ${ }^{2}$. Ekologišku produktų tvarkymo sertifikavimo sistemoje (EkoAgros) ši atlieka ịvardijama ir kaip kalkinè dirvos gerinimo priemonè. Cukraus gamybos metu susidaręs šalutinis produktas - kalkių purvas pasižymi aukštu $\mathrm{pH}$ rodikliu, todèl šiame tyrime ir buvo tikimasi sulaukti sunkiuosius metalus imobilizuojančio efekto.

Auginant greitai augančius augalus užterštame dirvožemyje ir tiriant jų biomasėje besikaupiančių sunkiųjų metalų kiekị galima ịvertinti sunkiųjų

2 Lietuvos Respublikos aplinkos ministro įsakymas 199907 14, Nr. 217 „Dèl atliekų tvarkymo taisyklių patvirtinimo“ [žiūrèta 2016-03-18]. Prieiga per internetą: https://www.e-tar.lt/portal/lt/legalAct/TAR.38E37AB6E8E6 
metalų judrumą ir stabilizuojančių priedų efektyvumą. Sumažejus sunkiųjų metalų judrumui dirvožemyje, mažesnis jų kiekis pateks i augalus ar vandenį, taip pat sumažès galimybe šiems pavojingiems teršalams per maisto grandinę pasiekti žmogų.

Šio darbo tikslas - ištirti šiltnamio sąlygomis užaugintų lapinių salotų gebą akumuliuoti sunkiuosius metalus iš užteršto dirvožemio ir įvertinti cukraus pramonès atliekų - kalkių purvo stabilizuojantị poveikị sunkiųjų metalų judrumui.

\section{MEDŽIAGOS IR METODAI}

Dirvožemio ir atliekų mėginių paėmimas bei substrato paruošimas. Lapinių salotų auginimo terpès, naudotos šio vegetacinio eksperimento metu, buvo paruoštos iš dirvožemio (D) ir nuotekų dumblo (ND). Kalkių purvas (KP) naudotas kaip SM stabilizuojantis priedas.

Anaerobiškai apdorotas nuotekų dumblas buvo paimtas iš Kauno nuotekų valymo ịrenginių po nusausinimo centrifugoje. Užterštam auginimo substratui paruošti naudotas natūralaus drègnumo ND. Sunkiụjų metalų analizei skirtas mėginys buvo išdžiovintas iki orasausès masès, susmulkintas, homogenizuotas ir persijotas per $2 \mathrm{~mm}$ sietą. Gravitometriniu metodu nustatytas dumble esančių sausų medžiagų kiekis.

Priesmèlio dirvožemis iš agrarinès teritorijos paviršinio sluoksnio $(0-20 \mathrm{~cm})$, be žinomos taršos, buvo naudojamas kaip švari kontrolinè auginimo terpé (D), taip pat ir užterštai auginimo terpei paruošti - dirvožemio-nuotekų dumblo mišiniams sudaryti (D-ND). Iš laukų parvežtas priesmèlio dirvožemis buvo išdžiovintas iki orasausès būsenos ir išsijotas, siekiant pašalinti stambesnius darinius: augalų šaknis, akmenis, po to homogenizuotas.

Kalkių purvas (defekatas) buvo paimtas iš UAB "Arvi cukrus“ gamybos atliekų sandèlių, išdžiovintas ir persijotas. Gravitometriniu metodu nustatytas kalkių purvo drègnumas.

Auginimo terpès paruoštos pagal schemą, pateiktą 1 pav. Dirvožemis buvo sumaišytas su nuotekų dumblu santykiu 1:1 sausų medžiagų ( $\mathrm{sm}$ ) masès pagrindu (D-ND). I gautą D-ND mišinị ịterptas sunkiuosius metalus stabilizuojantis priedas - kalkių purvas: 5, 10, $20 \%$ sausų medžiagų masès pagrindu (atitinkamai 5D-ND, 10D-ND, 20D-ND).

Vegetacinio eksperimento eiga. Paruoštos auginimo terpés buvo išpilstytos ị $3 \mathrm{dm}^{3}$ talpos plastikinius PE vazonus. I kiekvieną jų buvo pripilta po $2,5 \mathrm{dm}^{3}$ kontrolinio arba užteršto substrato ir pasètos lapinès salotos. Iš viso paruošti 4 skirtingi variantai su trimis pakartojimais.

Lapinès salotos augintos šiltnamyje 36 dienas vienodomis sąlygomis. Auginimo metu buvo palaikoma nekintanti $23 \pm 2{ }^{\circ} \mathrm{C}$ temperatūra. Optimaliam drègmès režimui palaikyti buvo naudojamas vienodas distiliuoto vandens kiekis. Nupjauti

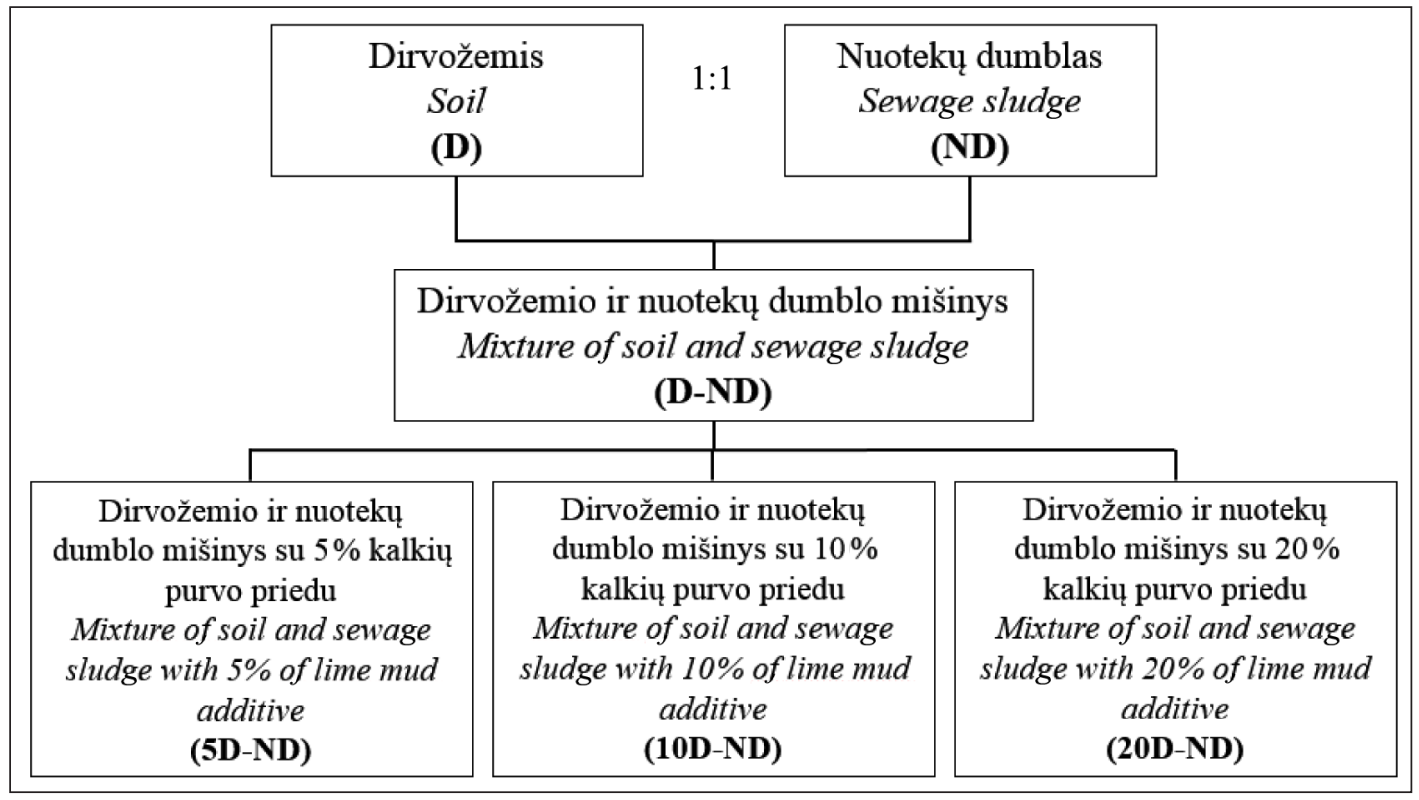

1 pav. Vegetaciniam eksperimentui skirtų auginimo terpių paruošimas

Fig. 1. Preparation of the growing media for the vegetative pot-experiment 
salotų lapai išdžiovinti termostate $60{ }^{\circ} \mathrm{C}$ temperatūroje, susmulkinti, homogenizuoti ir paruošti sunkiųjų metalų analizei. Sausa salotų biomasè supakuota ị švarius užspaudžiamus polietileno maišelius, laikoma sausoje, vėsioje, tamsioje vietoje iki tyrimų pradžios.

Sunkiųjų metalų analizè. Sunkiưjų metalų instrumentinè analizè atlikta indukuotos plazmos optinès emisijos spektroskopijos metodu (ICP-OES) naudojant Perkin-Elmer Optima 8000 ICP-OES spektrometrą, prieš tai mineralizavus méginius aukštame slègyje „šlapiuoju“ metodu.

Analitinèmis svarstyklèmis pasverti susmulkintos tiriamosios augalinès medžiagos mèginiai $(0.500 \pm 0.001 \mathrm{~g})$ buvo mineralizuoti slegiui atspariuose tefloniniuose indeliuose paeiliui užpilant $2 \mathrm{ml} 30 \%$ vandenilio peroksido $\left(\mathrm{H}_{2} \mathrm{O}_{2}\right), 5 \mathrm{ml}$ koncentruotos azoto rūgšties $\left(\mathrm{HNO}_{3}\right)$ ir $1 \mathrm{ml}$ dejonizuoto vandens. Organinès medžiagos skaidymas atliktas laboratoriniame mikrobangu mineralizatoriuje CEM Mars 5, pagal specialią programą keliant temperatūrą iki $195{ }^{\circ} \mathrm{C}$ ir išlaikant 10 minučių. Po mineralizacijos ekstraktai lètai atvėsinti ir praskiesti dejonizuotu vandeniu iki $100 \mathrm{ml}$.

Prieš atliekant vegetacinị eksperimentą $\mathrm{Cd}, \mathrm{Pb}$, $\mathrm{Cu}$ ir $\mathrm{Zn}$ koncentracijos buvo nustatytos kontroliniame dirvožemio mėginyje, nuotekų dumble, kalkių purve bei iš šių medžiagų paruoštose skirtingose auginimo terpèse.

Substrato ištraukos, kuriose buvo nustatoma bendroji sunkiųjų metalų koncentracija, gautos su aqua regia pagal ISO 11466: $1995^{3}$ metodiką.

Stikliniai indai ir kitos priemonès, naudojamos metalams nustatyti, buvo tinkamai plaunamos. Viso eksperimento metu naudoti tik gryni, cheminei analizei skirti reagentai. Rezultatų patikimumui užtikrinti buvo atliekama standartinių, žinomos koncentracijos mèginių, analizè.

Duomenų apdorojimas. Sunkiụjų metalų koncentracija spektrofotometriškai išmatuota mineralizatuose buvo perskaičiuota i SM koncentraciją sausoje biomasèje. Sunkiųjų metalų koncentracijos auginimo substratuose ir biomaseje išreikštos $\mathrm{mg} / \mathrm{kg} \mathrm{sm}$. Visi bandymai atlikti trimis pakartojimais, sunkiụjų metalų analizès rezultatai pateikiami kaip šių pakartojimų vidutinė reikšmè \pm stan-

ISO 11466: 1995. Soil Quality - Extraction of Trace Elements Soluble in Aqua Regia. Geneva: International Organization for Standardization, 1995. dartinė paklaida. Microsoft Office Excel programa apskaičiuotas ir ívertintas statistinis rezultatu patikimumas; vertès $p<0,05$ laikytos statistiškai reikšmingomis.

Metalų bioprieinamumui įvertinti apskaičiuotas akumuliacijos koeficientas $\left(K_{a}\right)$. Tai svarbus rodiklis, naudojamas nustatyti teršalų pernašą iš aplinkos it augalus. Pagal ši ryši gali būti prognozuojamas konkretaus elemento taršos lygis dirvožemyje. Akumuliacijos koeficientas apskaičiuojamas pagal (1) formulę:

$$
K_{a}=C_{a} / C_{d}
$$

$C_{a}$ - metalo koncentracija augalo audiniuose, $\mathrm{mg} / \mathrm{kg} \mathrm{sm}, C_{d}-$ metalo koncentracija dirvožemyje, kuriame augalai buvo auginami, $\mathrm{mg} / \mathrm{kg} \mathrm{sm}$ (Sun et al., 2011).

\section{REZULTATAI IR JŲ APTARIMAS}

Bendrosios sunkiųjų metalu koncentracijos auginimo terpèje bei jų komponentuose. Vidutinès bendrosios SM koncentracijos pateikiamos 2 lenteleje. Kontroliniame dirvožemyje bendrosios sunkiųjų metalų koncentracijos neviršijo Lietuvos aplinkosauginiame normatyviniame dokumente (LAND) $20-2005^{4}$ priesmèliams reglamentuojamu didžiausių leidžiamų koncentracijų (DLK). Ivairių šaltinių duomenimis, komunalinio nuotekų dumblo $\mathrm{pH}$ yra silpnai rūgštus ir jame būna susikaupę gana dideli sunkiųjų metalų kiekiai (United States..., 1992; Alloway et al., 2013). Kaip ir buvo tikètasi, nuotekų dumble bendrosios sunkiųjų metalų koncentracijos buvo kur kas didesnès nei kontroliniame dirvožemyje. Palyginus D-ND auginimo substrato bendrąsias sunkiųų metalų koncentracijas su LAND 20-2005 reglamentuojamomis DLK priesmèliuose, matyti, kad Cd viršija leidžiamą didžiausią koncentraciją 6,8 kartus, $\mathrm{Pb}-1,4$ kartus, $\mathrm{Cu}-5,1$ kartus, o $\mathrm{Zn}$ - net 8,6 kartus. Todèl galima teigti, kad paruošta auginimo terpè yra užteršta SM.

Sunkiųjų metalų koncentracijos salotų antžeminèje dalyje. Pagal Europos Komisijos parengtą

Dèl Lietuvos aplinkos apsaugos normatyvinio dokumento LAND 20-2005 „Nuotekų dumblo naudojimo tręšimui reikalavimü“. Lietuvos Respublikos aplinkos ministro ịsakymas 200511 28, Nr. D1-575 [žiūrèta 2015-01-20]. Prieiga per internetą: www.lrs.lt 
2 lentelè. Bendrosios sunkiųjų metalų koncentracijos auginimo terpèse ir pradinėse medžiagose

Table 2. Total concentrations of heavy metals in the growing media and their components

\begin{tabular}{|c|c|c|c|c|c|}
\hline \multirow{2}{*}{\multicolumn{2}{|c|}{$\begin{array}{l}\text { Mèginiai } \\
\text { Samples }\end{array}$}} & \multicolumn{4}{|c|}{$\begin{array}{l}\text { Sunkiojo metalo koncentracija } \mathrm{mg} / \mathrm{kg} \mathrm{sm} \\
\text { Heavy metal concentration, } \mathrm{mg} / \mathrm{kg} \mathrm{dm}\end{array}$} \\
\hline & & Cd & $\mathbf{P b}$ & $\mathrm{Cu}$ & Zn \\
\hline \multirow{3}{*}{$\begin{array}{l}\text { Pradinès medžiagos } \\
\text { Initial components }\end{array}$} & D & 0,2 & 9,4 & 12,7 & 22,3 \\
\hline & ND & 6,8 & 68,3 & 254,8 & 1373,7 \\
\hline & KP & 0,7 & 23,5 & 12,9 & 62,3 \\
\hline \multirow{4}{*}{$\begin{array}{l}\text { Auginimo terpès } \\
\text { Growing media }\end{array}$} & D-ND & 3,5 & 38,9 & 133,7 & 698,0 \\
\hline & 5D-ND & 3,3 & 37,4 & 127,7 & 664,2 \\
\hline & 10D-ND & 3,1 & 35,9 & 121,6 & 630,4 \\
\hline & 20D-ND & 2,8 & 33,0 & 109,5 & 562,9 \\
\hline
\end{tabular}

Pastaba / Note: ${ }^{*} d m$ - sausa masè / dry matter.

dokumentą ${ }^{5}$, drègnoje salotų masèje švino turi būti ne daugiau kaip $0,3 \mathrm{mg} / \mathrm{kg}$, o kadmio ne daugiau kaip $0,2 \mathrm{mg} / \mathrm{kg}$. Tam, kad būtų galima palyginti tyrimo metu gautus duomenis su didžiausiomis leidžiamomis koncentracijomis, daroma prielaida, kad visi sunkieji metalai ir jų junginiai, išgarinus vandenį (džiovinant biomasę), lieka sausoje dalyje. Remiantis J. A. T. Penningtono ir J. S. Douglasso (1994) duomenimis, vanduo salotose sudaro $95 \%$, todèl Europos Komisijos nustatytas DLK drègnoje maseje atitiktų tokias koncentracijas sausoje masèje: švinui - $6 \mathrm{mg} / \mathrm{kg}$, kadmiui - $4 \mathrm{mg} / \mathrm{kg}$. Kadangi varis ir cinkas yra augalams būtini mikroelementai, jų koncentracijos nèra reglamentuojamos.

5 Commission Regulation (EC) No. 1881/2006 setting maximum levels for certain contaminants in foodstuffs. 2016. The Commission of the European Communities [žiūrèta 2016-01-18]. Prieiga per internetą: http://eur-lex.europa.eu/legal-content/ LT/TXT/?qid=1453126057239\&uri=CELEX:32006R1881
Salotų vegetacija užterštoje terpeje nesiskyrè nuo salotų, auginamų švariame dirvožemyje, fitotoksinio efekto nebuvo pastebèta. Nors auginimo eksperimento metu lapinių salotų vegetacinis periodas buvo neilgas (36 d.), tačiau salotų audiniai sukaupé gana didelius sunkiųų metalų kiekius. Vidutinès sunkiųjų metalų koncentracijos ir standartiniai nuokrypiai antžeminejje salotų biomasèje pateikti 3 lentelèje.

Kalkių purvo įtaka kadmio perèjimui iš užterštos auginimo terpés i salotas parodyta 2 pav. Vidutinè kadmio koncentracija lapinèse salotose, užaugintose kontrolinejje neužterštoje terpejje (D), buvo $0,12 \pm 0,01 \mathrm{mg} / \mathrm{kg} \mathrm{sm}$, o užterštoje $\mathrm{D}$-ND terpèje - net 24 kartus didesnè $(2,88 \pm 0,45 \mathrm{mg} / \mathrm{kg} \mathrm{sm})$. Pastarajame méginyje kadmio koncentracija salotų lapų sausoje masejje buvo artima, tačiau neviršijo Europos Komisijos nustatytos ir pagal drègmès kieki perskaičiuotos DLK salotų audinių sausoje medžiagoje, kuri yra $4 \mathrm{mg} / \mathrm{kg}$. I auginimo terpę

3 lentelè. Sunkiụjų metalų koncentracijos salotų lapuose auginant skirtingose auginimo terpèse

Table 3. Heavy metal concentrations in lettuce leaves grown on different media

\begin{tabular}{|c|c|c|c|c|c|c|c|c|}
\hline \multirow{3}{*}{ 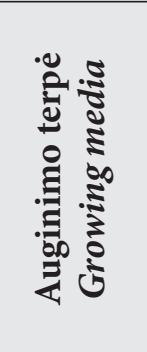 } & \multicolumn{8}{|c|}{$\begin{array}{l}\text { Sunkiojo metalo koncentracija salotų lapuose } \mathrm{mg} / \mathrm{kg} \mathrm{sm} \\
\text { Heavy metal concentration in lettuce leaves, } \mathrm{mg} / \mathrm{kg} \mathrm{dm}\end{array}$} \\
\hline & \multicolumn{2}{|r|}{ Cd } & \multicolumn{2}{|c|}{$\mathbf{P b}$} & \multicolumn{2}{|r|}{$\mathrm{Cu}$} & \multicolumn{2}{|c|}{$\mathrm{Zn}$} \\
\hline & 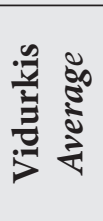 & 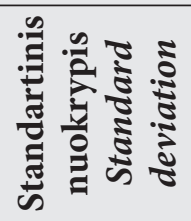 & 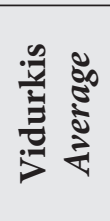 & 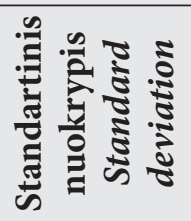 & 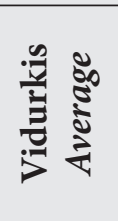 & 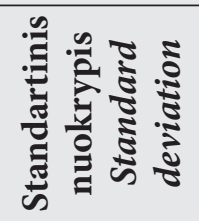 & 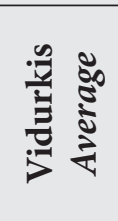 & 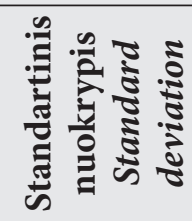 \\
\hline D & 0,12 & 0,01 & 0,38 & 0,03 & 3,14 & 0,22 & 32,24 & 3,17 \\
\hline D-ND & 2,88 & 0,45 & 6,14 & 0,29 & 45,98 & 3,15 & 392,44 & 37,25 \\
\hline 5D-ND & 1,88 & 0,31 & 5,34 & 0,51 & 37,87 & 3,42 & 226,24 & 14,11 \\
\hline 10D-ND & 1,73 & 0,33 & 5,33 & 0,43 & 42,97 & 1,74 & 183,27 & 8,210 \\
\hline 20D-ND & 0,94 & 0,10 & 2,84 & 0,10 & 36,15 & 2,51 & 141,69 & 12,17 \\
\hline
\end{tabular}




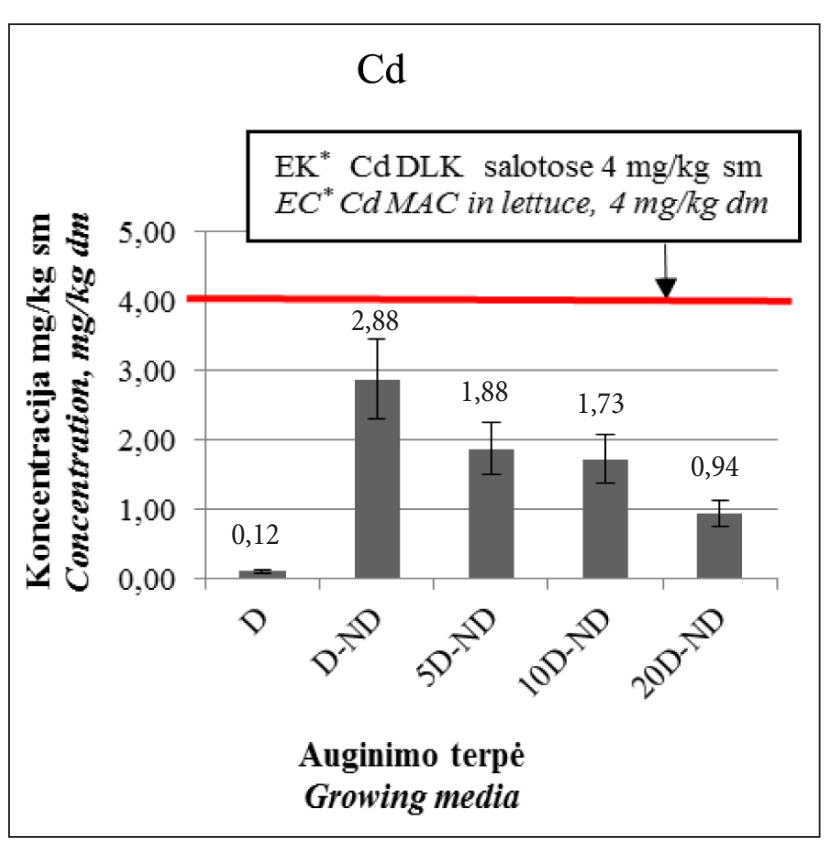

2 pav. Kadmio koncentracija salotų lapuose auginant skirtingose auginimo terpèse ( ${ }^{\star}$ EK - Europos Komisija) Fig. 2. Cadmium concentration in lettuce leaves grown on different media ( ${ }^{*}$ EC - European Commission)

pridejus SM stabilizuojančio priedo - kalkių purvo, kadmio koncentracija salotų lapuose statiškai patikimai sumažèjo $(p<0,01)$ dèl galimai susilpnejusio Cd judrumo substrate. Didžiausias SM stabilizuojantis efektas pasireiškè toje auginimo terpeje, kurioje kalkių purvo koncentracija buvo didžiausia - 20D-ND. Šio varianto salotų mėginyje Cd koncentracija $(0,94 \pm 0,10 \mathrm{mg} / \mathrm{kg} \mathrm{sm})$ buvo net 3 kartus mažesnè nei salotose, užaugintose nestabilizuotame dirvožemio ir nuotekų dumblo mišinyje D-ND. Rezultatai rodo, kad kadmio judrumas užterštuose substratuose su stabilizuojančiu priedu buvo atvirkščiai priklausomas nuo įdèto kalkių purvo kiekio - kuo didesnè KP koncentracija, tuo Cd akumuliacija salotose buvo silpnesnè.

Švino akumuliacija salotose, užaugintose skirtingose terpèse, pateikta 3 pav. Didžiausia švino koncentracija salotų audinių sausoje medžiagoje buvo aptikta auginant jas nestabilizuotame dirvožemio ir nuotekų dumblo substrate $\mathrm{D}$-ND: $6,14 \pm 0,29 \mathrm{mg} / \mathrm{kg} \mathrm{sm}$. Ji buvo net $16 \mathrm{kartuc} \mathrm{di-}$ desnè nei kontroliniame salotų biomasès mèginyje $(0,38 \pm 0,03 \mathrm{mg} / \mathrm{kg} \mathrm{sm})$ ir siekè Europos Komisijos nustatytą ir pagal drégmès kieki perskaičiuotą DLK salotų audinių sausoje medžiagoje $-6,0 \mathrm{mg} / \mathrm{kg}$. Didžiausias ir statiškai patikimas

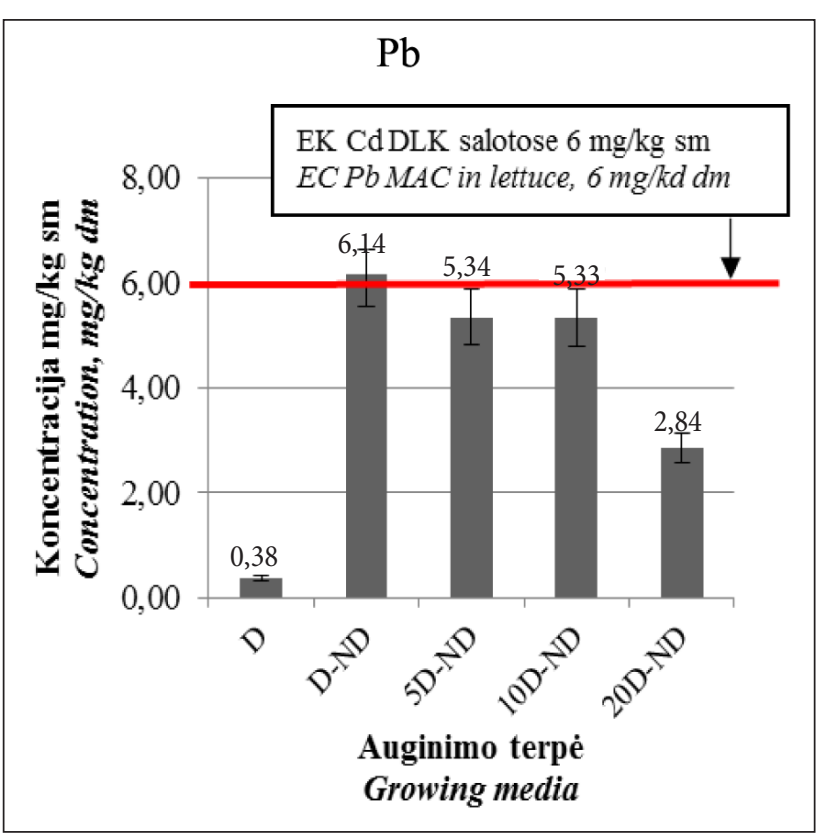

3 pav. Švino koncentracija salotų lapuose auginant skirtingose auginimo terpèse

Fig. 3. Lead concentration in lettuce leaves grown on different media

$(p=0,002) \mathrm{Pb}$ koncentracijos sumažejimas užfiksuotas salotose, užaugintose terpèje su didžiausia kalkių purvo koncentracija (20D-ND). Pastarajame variante $\mathrm{Pb}$ koncentracija salotų audiniuose $(2,84 \pm 0,10 \mathrm{mg} / \mathrm{kg} \mathrm{sm})$ buvo net 2 kartus mažesné, nei auginant salotas D-ND mišinyje be kalkių purvo priedo. Gauti rezultatai, kaip ir kadmio atveju, patvirtina mokslinejje literatūroje rastus teiginius, kad šie du nebiogeniniai elementai dirvožemyje yra mažiau judrūs neutralioje ir šarminèje terpejje (Kabata-Pendias, 2011).

Vario koncentracijos kitimas salotose, augintose skirtingose terpése, pavaizduotas 4 pav. Auginant kontroliniame dirvožemio substrate $\mathrm{D}$, vidutinè $\mathrm{Cu}$ koncentracija sausoje lapinių salotu biomaseje buvo 3,14 $\pm 0,22 \mathrm{mg} / \mathrm{kg}$. Nestabilizuotame D-ND substrate augintose salotose ši koncentracija buvo net 14,6 kartus didesnè ir sieké $45,98 \mathrm{mg} / \mathrm{kg} \mathrm{sm}$. Pridejus kalkių purvo, $\mathrm{Cu}$, prieinamumo salotoms sumažejimas buvo statistiškai reikšmingas, tačiau tik 5D-ND $(p=0,04)$ ir 20DND $(p=0,007)$ atvejais. Mažiausią ittaką vario koncentracijos pasikeitimui salotose turejjo $10 \%$ KP priedas, palyginti su salotomis, užaugintomis nestabilizuotame D-ND mišinyje.

Cinko koncentracijos kitimas lapinių salotu antžeminëje dalyje parodytas 5 pav. Vidutinè $\mathrm{Zn}$ 


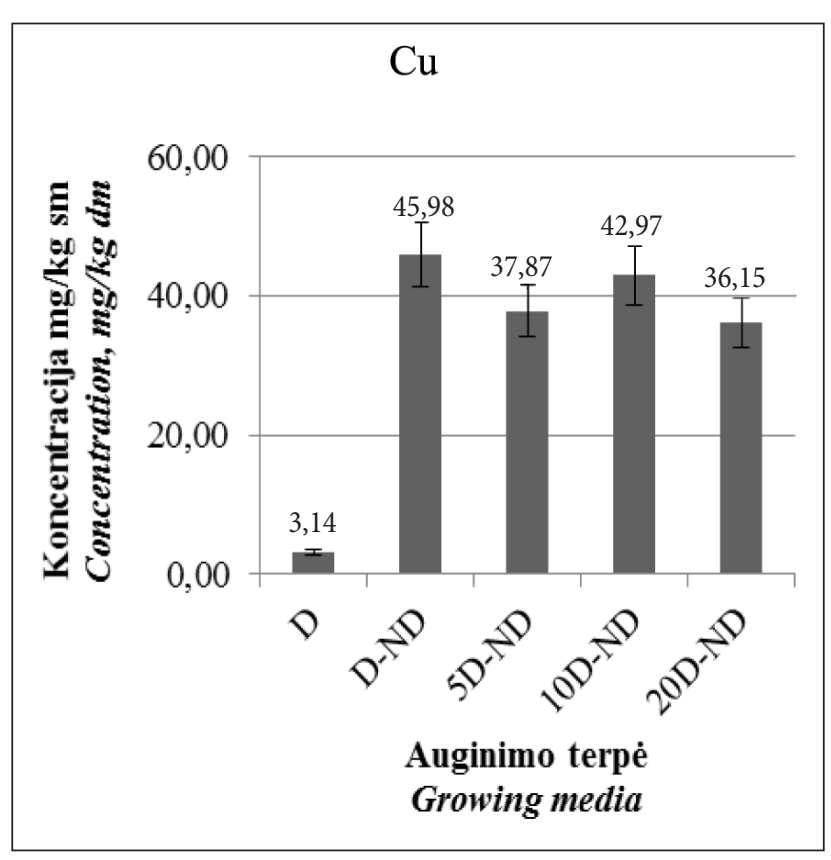

4 pav. Vario koncentracija salotų lapuose auginant skirtingose terpèse

Fig. 4. Copper concentration in lettuce leaves grown on different media

koncentracija kontroliniame mèginyje buvo $32,24 \pm 3,17 \mathrm{mg} / \mathrm{kg} \mathrm{sm}$, o užterštame substrate D-ND užaugintose salotose siekè net $392,44 \pm 37,25 \mathrm{mg} / \mathrm{kg}$ sm.Pridejus kalkių purvo,

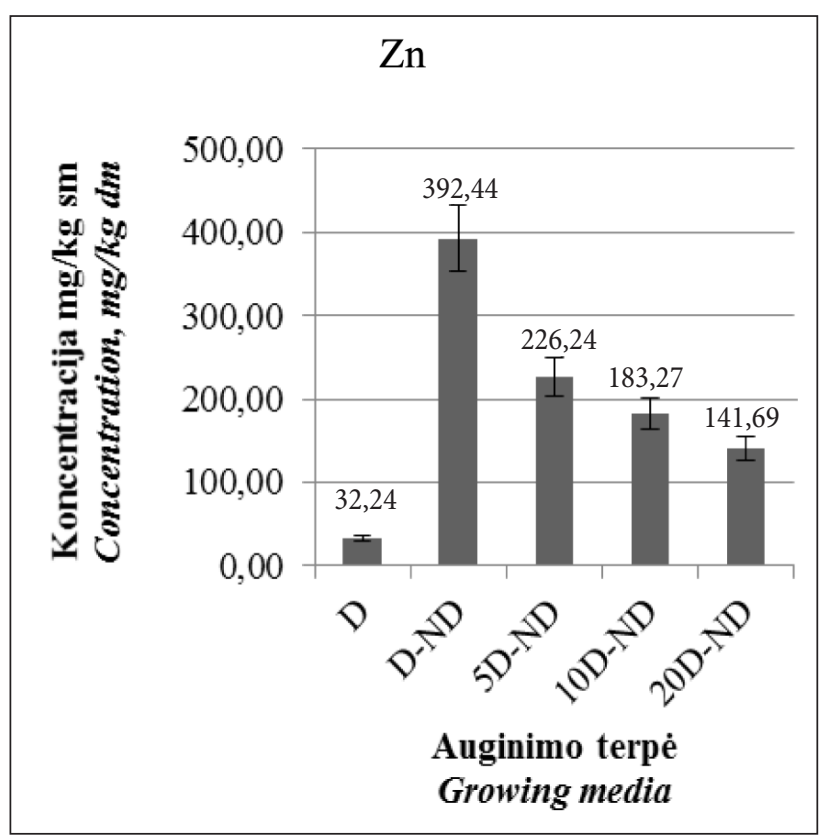

5 pav. Cinko koncentracija salotų lapuose auginant skirtingose terpèse

Fig. 5. Zinc concentration in lettuce leaves grown on different media
Zn koncentracija salotų lapuose statistiškai patikimai sumažejo - stebima panaši tendencija, kaip $\mathrm{Cd}$ ir $\mathrm{Pb}$ atveju. Didžiausias ir statistiškai patikimas $(p<0,008)$ Zn koncentracijos sumažejimas nustatytas tame variante, kuriame naudota didžiausia kalkių purvo koncentracija (20D-ND): Zn koncentracija buvo net 2,8 kartus mažesnè nei salotose, augintose užterštame, bet nestabilizuotame dirvožemio ir nuotekų dumblo substrate D-ND. Cinko bioprieinamumas užterštuose substratuose su kalkių purvo priedu buvo atvirkščiai priklausomas nuo naudoto kalkiu purvo kiekio. Šie tyrimo rezultatai patvirtina moksliniuose šaltiniuose rastą informaciją, kad $\mathrm{Zn}$ judrumas būna didesnis esant mažesniam terpès $\mathrm{pH}$, o jam didejant, judrumas mažèja (Kabata-Pendias, 2011).

Sunkiųjų metalų akumuliacijos geba salotose. Elementinès analizès duomenys rodo (1 lentelè), kad didinant kalkiu purvo, kaip SM stabilizuojančio priedo, kieki mišiniuose, bendroji visų sunkiųjų metalų koncentracija užterštame substrate mažeja. Taip vyksta todèl, kad kalkių purve esantis sunkiųjų metalų kiekis yra gerokai mažesnis, negu vegetacinio eksperimento metu naudotame užterštame substrate. Akivaizdu, kad būtent šis taršos sumažejimas gali lemti ir mažesnes SM koncentracijas salotų biomaseje. Todèl sunkiųjų metalų bioprieinamumui įvertinti patogiau naudoti akumuliacijos koeficientą $\left(K_{a}\right)$, kuris yra santykinis dydis, priklausantis ir nuo SM koncentracijos auginimo substrate. Kadmio, švino, vario ir cinko akumuliacijos koeficientai lapinèms salotoms, užaugintoms skirtinguose substratuose, pateikti 6 pav.

Kontroliniame variante kadmio akumuliacijos koeficientas buvo lygus 0,75 . Ruošiant substratą su nuoteku dumblu, kuriame Cd koncentracija buvo didesnè 34 kartus nei $\mathrm{D}$ auginimo terpèje, bendroji kadmio koncentracija D-ND mišinyje „prasiskiede“" ir sumažèjo beveik 2 kartus. Salotoms, užaugintoms D-ND terpeje, akumuliacijos koeficientas padidejo tik $10 \%$, palyginti su kontroliniame substrate $\mathrm{D}$ užaugintomis salotomis (6 pav.). Kalkių purvo priedas mažino Cd bioprieinamumą salotoms - tai patvirtina mažejantys akumuliacijos koeficientai, didejjant KP priedo koncentracijai užterštame substrate. Mažiausias akumuliacijos koeficientas $(0,33)$ nustatytas tame variante, kuriame buvo naudojama didžiausia kalkių purvo koncentracija. 


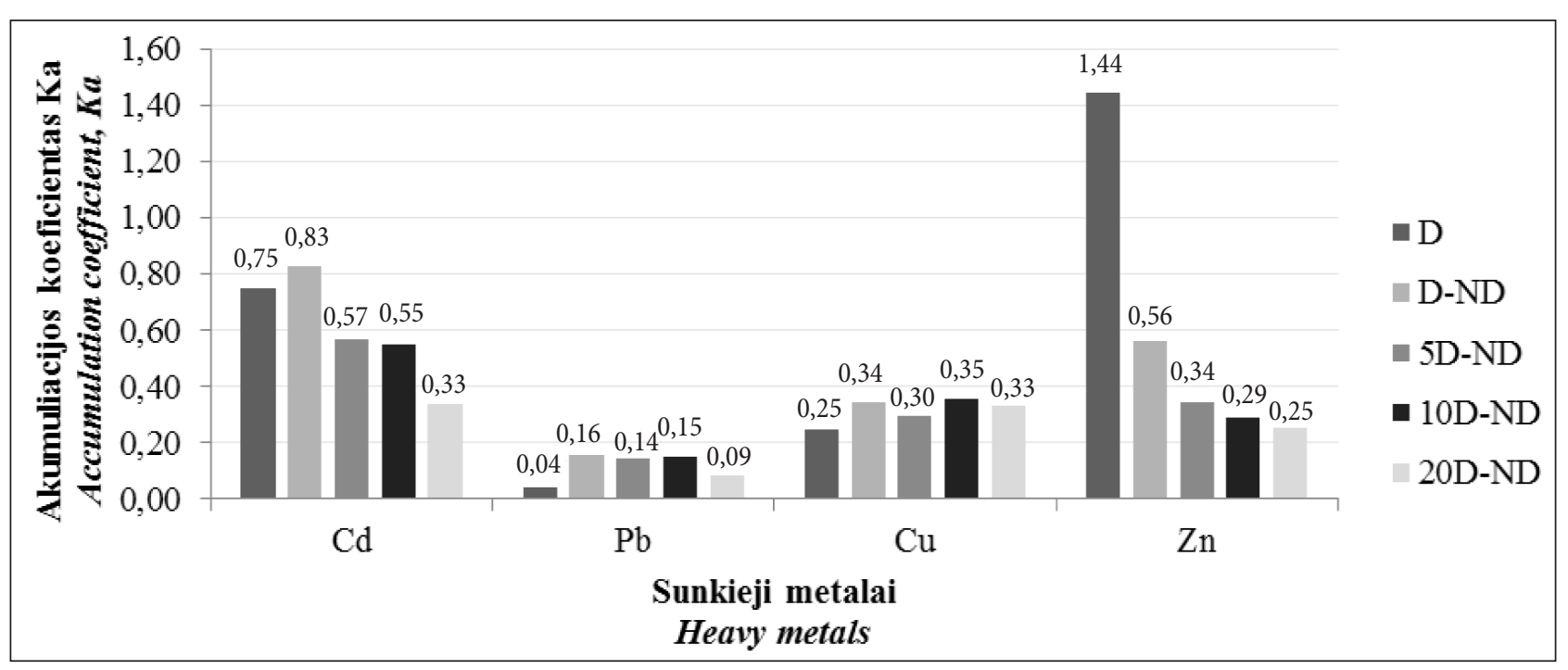

6 pav. Sunkiųjų metalų akumuliacijos koeficientai salotoms, augintoms skirtingose auginimo terpèse Fig. 6. Heavy metal accumulation coefficients for lettuce grown on different media

Švino akumuliacijos koeficientas kontroliniame dirvožemyje užaugintoms salotoms siekè 0,04. Pridèjus nuotekų dumblo, kuriame $\mathrm{Pb}$ koncentracija buvo didesne 7,3 kartus nei $\mathrm{D}$ auginimo terpeje, bendroji švino koncentracija D-ND mišinyje sumažèjo 1,8 kartus. Salotoms, užaugintoms D-ND terpeje, akumuliacijos koeficientas padidejo 4 kartus, palyginti su $\mathrm{D}$ terpeje vykdytu vegetaciniu bandymu (6 pav.). 5 ir $10 \%$ kalkių purvo priedai didelès reikšmingos ịtakos $\mathrm{Pb}$ judrumui nedarè $(p=0,06)$. Tačiau $20 \%$ kalkių purvo priedas sumažino akumuliacijos koeficientą 1,8 karto, palyginti su variantu, kuriame stabilizuojantis priedas nebuvo naudojamas. Vario akumuliacijos koeficientas mažiausias buvo kontroliniame variante $(0,25)$. Pridejus nuoteku dumblo, kuriame $\mathrm{Cu}$ koncentracija buvo didesnè 20 kartų nei $\mathrm{D}$ auginimo terpeje, bendroji vario koncentracija D-ND mišinyje sumažejo beveik 2 kartus, palyginti su ND terpejje rasta bendrąja $\mathrm{Cu}$ koncentracija. Akumuliacijos koeficientas salotoms, užaugintoms D-ND terpeje, buvo 1,4 karto didesnis $(0,34)$ nei salotoms, užaugintoms kontroliniame substrate (6 pav.). Pradinè kalkių purvo dozè sumažino Cd bioprieinamumą, tačiau 10 ir $20 \%$ kalkių purvo priedas reikšmingos ịtakos akumuliacijos koeficiento pasikeitimui neturejjo $(p<0,06)$. Statistiškai patikimas mažiausias akumuliacijos koeficientas $(0,30)$ nustatytas esant mažiausiai kalkių purvo koncentracijai 5D-ND mėginyje.
Cinko akumuliacijos koeficientas pats didžiausias iš visų vegetacinio bandymo variantų buvo kontroliniame méginyje. Toks aukštas rodiklis galètų būti aiškinamas tuo, kad $\mathrm{Zn}$ yra būtinas mikroelementas augalams, todèl lapinès salotos intensyviai ji akumuliavo, nepaisant to, kad jo koncentracija dirvožemyje buvo nedidelè $(22,3 \mathrm{mg} / \mathrm{kg} \mathrm{sm})$. D-ND mišinyje bendroji $\mathrm{Zn}$ koncentracija sumažejo per pusę, palyginti su ND substrate nustatyta bendrąja Zn koncentracija. Esant didesnei Zn koncentracijai auginimo terpeje, lapinèse salotose sukauptas $\mathrm{Zn}$ kiekis buvo didesnis, tačiau akumuliacijos koeficientas sumažejo. Kalkių purvo priedas akivaizdžiai mažino $\mathrm{Zn}$ akumuliaciją salotose, todèl galima daryti išvadą, kad $\mathrm{Zn}$ judrumas, taip pat ir jo bioprieinamumas auginimo terpèse didejant $\mathrm{KP}$ koncentracijai irgi mažèjo (6 pav.). Mažiausias akumuliacijos koeficientas $(0,25)$ nustatytas variante, kuriame salotos augintos esant didžiausiai kalkių purvo priedo koncentracijai (20\%).

Remiantis anksčiau pateiktais akumuliacijos koeficientų rezultatais, matyti, kad sunkieji metalai pagal akumuliacijos gebą salotose, augintose kontroliniame (neužterštame) dirvožemyje, išsidésto tokia tvarka: $\mathrm{Zn}>\mathrm{Cd}>\mathrm{Cu}>\mathrm{Pb}$, o SM akumuliacijos eiliškumas užterštame dirvožemyje yra toks: $\mathrm{Cd}>\mathrm{Zn}>\mathrm{Cu}>\mathrm{Pb}$. Taip pat matyti, kad kalkiu purvo priedas sunkiųjų metalų prieinamumą lapinèms salotoms labiausiai mažino kadmiui, cinkui, mažiau švinui ir mažiausiai variui. Didejjant 
stabilizuojančio priedo koncentracijai substrate nuo 5 iki $20 \%$, Cd ir Zn akumuliacija salotose statistiškai reikšmingai mažejo $(p<0,005)$. Švino atveju statistiškai patikimas akumuliacijos sumažejimas stebètas tik esant didžiausiai kalkių purvo koncentracijai (20\%). Vario atveju statistiškai reikšmingo akumuliacijos skirtumo tarp trijų skirtingų stabilizuoto substrato variantų nebuvo.

\section{IŠVADOS}

1. Nustatyta, kad bendrosios sunkiųu ų metalu koncentracijos dirvožemio ir nuotekų dumblo substrate buvo didesnès už LAND 20-2005 reglamentuojamas DLK priesmèliams: Cd - 6,8, $\mathrm{Pb}-1,4, \mathrm{Cu}-5,1$ ir $\mathrm{Zn}-8,6$ kartus.

2. Kadmio koncentracija salotose, užaugintose užterštame dirvožemyje $(2,88 \mathrm{mg} / \mathrm{kg} \mathrm{sm})$, buvo artima, tačiau neviršijo Europos Komisijos nustatytos DLK salotoms (4 mg/kg sm), o švino koncentracija salotose $(6,14 \mathrm{mg} / \mathrm{kg} \mathrm{sm})$, užaugintose užterštame dirvožemyje, sieke Europos Komisijos nustatytą DLK ribą (6 mg/kg sm).

3. Apskaičiavus bioakumuliacijos koeficientus nustatyta, kad sunkieji metalai pagal akumuliacijos gebą salotose, augintose švariame dirvožemyje, išsidèsto tokia tvarka: $\mathrm{Zn}>\mathrm{Cd}>\mathrm{Cu}>\mathrm{Pb}$; sunkiųjų metalų akumuliacijos eiliškumas užterštame dirvožemyje: $\mathrm{Cd}>\mathrm{Zn}>\mathrm{Cu}>\mathrm{Pb}$.

4. Nustatyta, kad kalkių purvo priedas sunkiųjų metalų bioprieinamumą lapinèms salotoms užterštame dirvožemyje mažino taip: $\mathrm{Cd} \approx \mathrm{Zn}>\mathrm{Pb}>\mathrm{Cu}$. Cinko ir kadmio kaupimasis salotose reikšmingai mažèjo didinant stabilizuojančio priedo koncentraciją nuo 5 iki $20 \%$. Statistiškai patikimas švino akumuliacijos sumažejimas pastebètas tik esant didžiausiai kalkių purvo koncentracijai. Vario atveju statistiškai reikšmingo akumuliacijos skirtumo tarp trijų skirtingu stabilizuoto substrato variantu nebuvo.

Gauta 20160119 Priimta 20160308

\section{LITERATŪRA}

1. Bolan N. S., Adriano D. D., Curtin D. 2014. Soil acidification and liming interactions with nutrient and heavy metal transformation and bioavailability. Advances in Agronomy. Vol. 78. P. 215-272.
2. Brown S., Chaney R., Lloyd C., Angle J., Ryan J. 1996. Relative uptake of cadmium by garden vegetables and fruits grown on long-term biosolid-amended soils. Environmental Sciences \& Technology. Vol. 30. P. 3508-3511.

3. Burnham J. C., Hatfield N., Bennett G. F., Logan T. J. 1992. Use of Kiln Dust with Quicklime for Effective Municipal Sludge Pasteurization and Stabilization with the N-Viro Soil Process. ASTM Special Technical Publication. Vol. 1135. P. 128-141.

4. Butnariu M. 2012. Vegetable bioindicators of heavy metal pollution. Journal of Ecosystem and Ecography. Vol. 2. P. 114.

5. Kabata-Pendias A. 2011. Trace Elements in Soils and Plants. CRC Press. 534 p.

6. Keller C., McGrath S. P., Dunham S. J. 2002. Trace metal leaching through a soil-grassland system after sewage sludge application. Journal of Environmental Quality. Vol. 31. P. 1550-1560.

7. Kumpiene J., Lagerkvist A., Maurice C. 2008. Stabilization of $\mathrm{As}, \mathrm{Cr}, \mathrm{Cu}, \mathrm{Pb}$ and $\mathrm{Zn}$ in the soil using amendments - A review. Waste Management. Vol. 28. P. 215-225.

8. Beesley L., Marmiroli M., Pagano L., Pigoni V., Fellet G., Fresno T., Vamerali T., Bandiera M., Marmiroli N. 2013. Biochar addition to an arsenic contaminated soil increases arsenic concentrations in the pore water but reduces uptake to tomato plants (Solanum lycopersicum L.). Science of the Total Environment. Vol. 454-455. P. 598603.

9. Mendez A., Gomez A., Pazz-Ferreiro J., Gasco G. 2012. Effects of sewage sludge biochar on plant metal availability after application to a Mediterranean soil. Chemosphere. Vol. 89. P. 1354-1359.

10. Moirou A., Xenidi A., Papaliaris A. 2001. Stabilization of $\mathrm{Pb}, \mathrm{Zn}$ and $\mathrm{Cd}$-contaminated soils by means of natural zeolite. Soil and Sediment Contamination. Vol. 10. P. 251-267.

11. Pennington J. A. T., Douglass J. S. 1994. Bowes \&Church's: Food Values of Portions Commonly Used [žiūrèta 2016-01-18]. Prieiga per internetą: https://books.google.lt/books?id=LTGFV2NOySYC\&pg=PA322\&lpg=PA322\&dq=Bowes + $\% 26+$ Church\%E2\%80\%99s+Food+Values, + 1994 \&source $=\mathrm{bl} \&$ ots $=\mathrm{X} 6 \mathrm{xm} 5 \mathrm{hkzF} \& \operatorname{sig}=\mathrm{mPxETlIKyR}-$ fhRSbzWEQf4S1Ygfs\&hl=lt\&sa=X\&ei=hctQVe30v7ywP83YDwCQ\&ved=0CCIQ6AEwAA\#v=onepage\&q=Bowes $\% 20 \% 26 \% 20$ Church $\%$ E2\%80\%99s\%20 Food\%20Values $\% 2$ C\%201994\&f=false

12. Petruzzelli G., Barbafieri M., Bretzel F., Pezzarossa B. 1998. In situ Attenuation of Heavy Metal Mobility in Contaminated Soil by Use of Paper Mill Sludge. Contaminated Soil. London: Thomas Telford Publishing. $1140 \mathrm{p}$.

13. Querol X., Alastucy A., Moreno N. 2006. Immobilization of heavy metals in polluted soils by the addition 
of zeolite material synthesized from coal fly ash. Chemoshpere. Vol. 62. P. 171-180.

14. McLaren R. G., Clucas L. M., Taylor M. D. 2005. Leaching of macronutrients and metals from undisturbed soils treated with metal-spiked sewage sludge. Distribution of residual metals. Australian Journal of Soil Research. Vol. 43. No. 2. P. 159-170.

15. Sun Y., Zhou Q., Xu Y., Wang L., Liang X. 2011. The role of EDTA on cadmium phytoextraction in a cadmium-hyperaccumulator Rorippa globosa. Journal of Environmental Chemistry and Ecotoxicology. Vol. 3. No. 3. P. 45-51.

16. Šlapakauskas V., Kučinskas J. 2008. Augalu mityba. Akademija. 298 p.

17. United States Environmental Protection Agency. 1992. Technical Support Document for Land Application of Sewage Sludge: EPA-822/R-93-00l. Washington: Office of Water.

18. Van Wyk B. E. 2005. Lactuca sativa. Food Plants of the World: An Illustrated Guide. Portland: Timber Press. $222 \mathrm{p}$.

19. Wu L., Li Z., Akahane I., Liu L., Han C., Makino T., Luo Y., Christie P. 2012. Effects of organic amendments on $\mathrm{Cd}, \mathrm{Zn}$ and $\mathrm{Cu}$ bioavailability in soil with repeated phytoremediation by Sedum plumbizincicola. International Journal of Phytoremediation. Vol. 14. P. 1024-1038.

20. Du Y.-J., Wei M.-L., Reddy K. R., Jin F., Wu H.-L., Liu Z.-B. 2014. New phosphate-based binder for stabilization of soils contaminated with heavy metals: Leaching, strength and microstructure characterization. Journal of Environmental Management. Vol. 146. P. 179-188.

21. Zubbilaga M. S., Lavado S. R. 2002. Heavy metal content in lettuce plants grown in biosolids compost. Compost Science and Utilization. Vol. 10. P. 363-367.
Eglè Barkauskaité, Alfreda Kasiulienė, Valdas Paulauskas, Giedrius Šlekys

\section{ACCUMULATION OF HEAVY METALS IN \\ LETTUCE (Lactuca sativa L.) GROWN ON LIME-MUD STABILISED SUBSTRATE}

Summary

Heavy metal accumulation in lettuce (Lactuca sativa L.) grown on lime-mud stabilised contaminated soil-sludge substrate was investigated in this work. It was found that total heavy metal concentrations in the soil and sewage sludge substrate were higher than the maximum permissible concentrations in soils by LAND 20-2005: 6.8 times for $\mathrm{Cd}, 1.4$ for $\mathrm{Pb}, 5.1$ for $\mathrm{Cu}$ and 8.6 times for $\mathrm{Zn}$. The vegetative experiment showed that the concentration of $\mathrm{Cd}(2.88 \mathrm{mg} / \mathrm{kg} \mathrm{dm})$ in lettuce crops grown on the heavy metal contaminated substrate was close, but did not exceed the maximum allowable concentration for lettuce $(4 \mathrm{mg} /$ $\mathrm{kg} \mathrm{dm}$ ), established by the European Commission, while the $\mathrm{Pb}$ concentration $(6.14 \mathrm{mg} / \mathrm{kg} \mathrm{dm})$ was slightly higher than the maximum allowable concentration $(6 \mathrm{mg} / \mathrm{kg} \mathrm{dm})$. The studied heavy metals according to their accumulation capacity in lettuce grown on the contaminated soilsludge substrate can be ranked as follows: $\mathrm{Cd}>\mathrm{Zn}>\mathrm{Pb}>\mathrm{Cu}$. Lime-mud additive decreased heavy metal bioavailability by lettuce grown on contaminated soil in the following order: $\mathrm{Cd} \approx \mathrm{Zn}>\mathrm{Pb}>\mathrm{Cu}$. Cadmium and zinc bioaccumulation in lettuce decreased with increasing the concentration of lime-mud additive in the substrates. Accumulation of lead was significantly decreased only when the highest (20\%) concentration of lime mud was added. No statistically significant differences between accumulation values were observed in the case of $\mathrm{Cu}$.

Keywords: lettuce, heavy metals, bioavailability, accumulation, lime mud, sewage sludge 